Universal Decimal Classification (UDC) number 613.27

\title{
MICRONUTRIENT DEFICIENCY AND MECHANISMS OF ITS REGULATION IN THE SARATOV REGION
}

\section{S.V. Sergeyeva, O.I. Kozhanova, A.V. Khan, N.K. Fomicheva}

Saratov Region Department of the Federal Service on Customers' Rights Protection and Human Well-Being Surveillance, Russian Federation, Saratov, 7 Volskaya St., 410028

\begin{abstract}
The problem of vitamin and micronutrient deficiency is relevant to all regions of the Russian Federation. The present article evaluates actual features of the prevalence of micronutrient deficiencies in the Saratov region. Based on an integrated approach, the development of a controlled system is proposed for identification, correction and prevention of children's health disorders related to the risk of micronutrient deficiency.

Key words: population, nutrition, micronutrients, deficiency, morbidity of adults and children, prevention, control mechanisms.
\end{abstract}

One of the priority activities of the government authorities in preserving the health of the population of the Russian Federation is the implementation of "The Fundamentals of the state policy in the sphere of healthy nutrition for the time period up to 2020" (2010). The strategy of national programs is also aimed at the control of diseases associated with a deficiency of certain vitamins and minerals, including iodine.

The problem of vitamin and micronutrient deficiency is one of the most critical. Nearly half of children living in Russia have a deficiency of essential vitamins and micronutrients (trace elements), there are some regions, where such deficiency is observed in $80 \%$ of children. Lack of vitamins $\mathrm{A}, \mathrm{B}$ and $\mathrm{E}$ and carotenoids is registered in the vast majority of children living in major cities $[1,5-7]$.

The Government Decree No. 1119 "On Measures for the prevention of iodine deficiency" adopted in 1999 has contributed to the resumption of investigation and elimination of the problem at the governmental level.

Taking the above mentioned into consideration, it is extremely important to assess the current prevalence of micronutrient deficiency in the Saratov region, which is endemic for iodine deficiency, and, based on an integrated approach to the endemicity assessment, to develop a

(C) Sergeyeva S.V., Kozhanova O.I., Khan A.V., Fomicheva N.K., 2013

Sergeyeva Svetlana Vladimirovna - PhD in Medicine, Deputy Head (e-mail: Sergeeva_SV@64.rospotrebnadzor.ru, tel.: 8 (852) 20-18-58).

Kozhanova Olga Ivanovna - Head (e-mail: Koganova_OI@64.rospotrebnadzor.ru, tel.: 8 (842) 20-18-58).

Khan Alexandr Vladimirovich - Head of Social and Environemntal Health Monitoring (e-mail: Khan_AV@64.rospotrebnadzor.ru, tel.: 8 (842) 22-89-75).

Fomicheva Natalya Konstantinovna - Chief Specialist-Expert of the Department of Food Hygiene (e-mail: Fomicheva NK@, 64.rospotrebnadzor.ru, tel.: 8 (842) 22-88-48). 
controlled system for identification, correction and prevention of children's health disorders related to the risk of micronutrient deficiency, in the ecosystem of the region.

Groups at risk for micronutrient deficiency inlcude children in critical periods of growth (younger than 3 years old, 5-7 years, in the puberty period - 11-15 years old), children during social and biological adaptation (first-grade pupils, pupils in the transition to subject teaching and during examination period). A special risk group includes children with long-term and reccurent respiratory infections [2, 4, 6-11].

In 2012 in the region 8.9 thousand cases of diseases related to micronutrient deficiency were reported, which is similar to the level registered in 2011. The proportion of annual child morbidity is from 30 to $32 \%$ of all for the first time registered cases of micronutrient deficiency.

The primary morbidity rate among children under 14 years in 2012 was 7.9 per 1000 children in the region and this was similar to that in 2011. The rate of morbidity associated with micronutrient deficiency among children in the past three years most often exceeded the average regional data in the following raions: Novoburassky - 3-fold, Engelsky - 1.5 to 3- fold, Turkovsky - 2 to 3.8- fold, Romanovsky - 2- fold, Osinsky - 1.5- fold (Figure 1).

The primary morbidity rate in the adult population in 2012 amounted to 2.9 per 1000 adults, which is similar to the rates of 2011 and 2010. The morbidity rate in the adult population over the last three years most often exceeded the average regional data in the following raions: Novouzensky - 2-fold, Osinsky - 2-fold, Balakovsky - 1.5-fold (Figure 2).

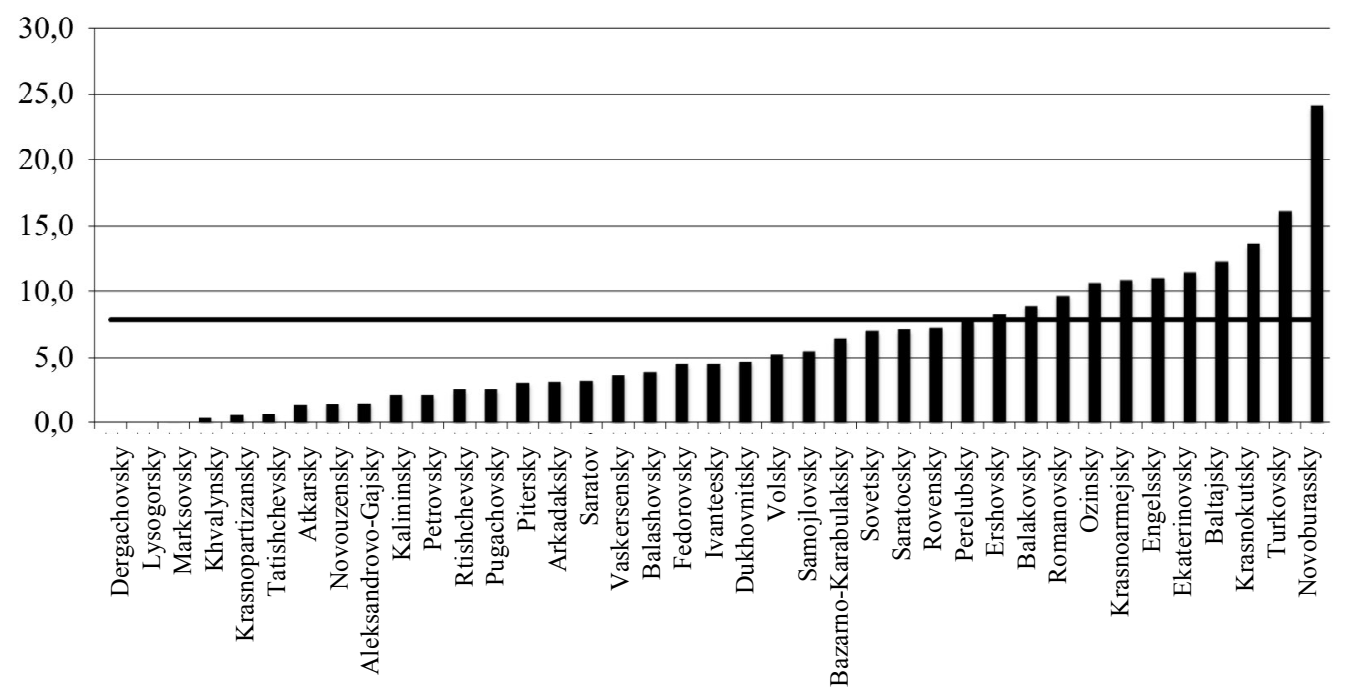

Average regional rate 7.9

Figure 1. Ranking of the areas of the Saratov region according to the level of micronutrient deficiency among children in 2012 (per 1000 children) 


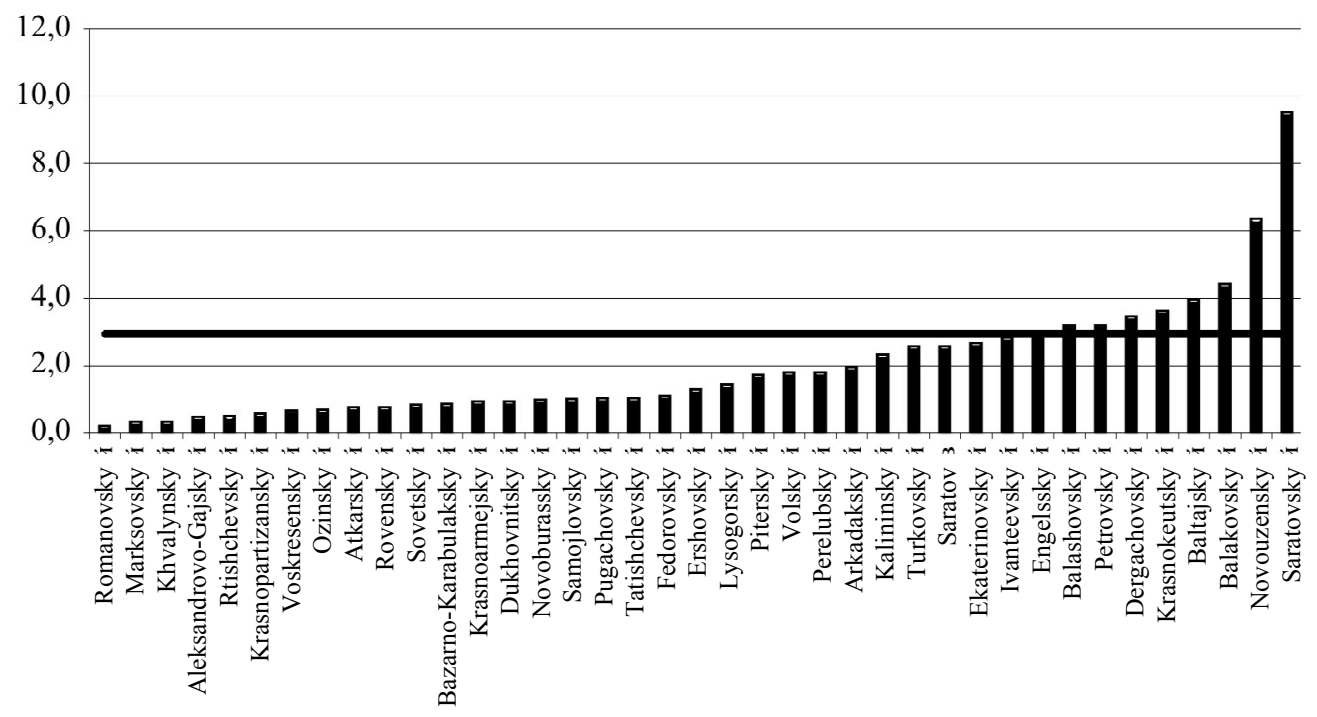

Average regional rate 2.9

Figure 2. Ranking of the areas or tne Saratov region accoraing to the level of micronutrient deficiency among adults in 2012 (per 1000 adults)

Analysis of ecological, hygienic and epidemiological environment in the region allowed us to determine the starting mechanisms of the effects of environmental pollutants on human health, their routes of entry in the body and the effect ("dose-risk-disease"). The scheme of formation of a risk to public health helps to determine the mechanisms of the effect on the human body and a range of preventive measures (Figure 3).

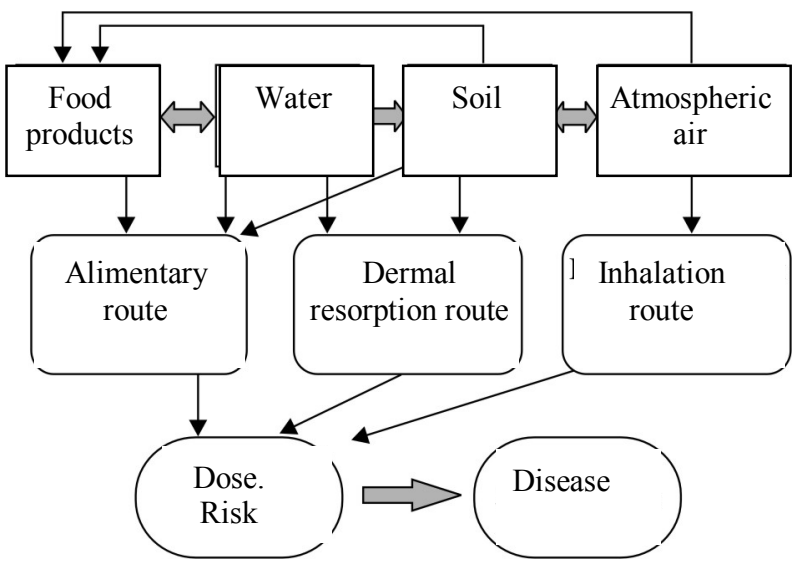

Figure 3. The scheme of formation of a risk to public health

Mechanisms of management of negative impact of the environmental factors on the human health can only include the governmental administrative systems, which are based on legislative acts, execution of which is under control. Management mechanisms established during the study include targeted programs developed in the region on our initiative, which include scientifically substantiatiated approaches to diet correction for children and adolescents in the region - "Prevention of family troubles and social orphanhood of minors in the Saratov region in 2011-2013", "Accessible environment for 2011-2013", "Development of education in 
the Saratov region for 2013-2015", subprogram "Healthy generation", "Organization of rest, health improvement and employment of children and adolescents", "On additional measures for improvement of the demographic situation in the Saratov region", "Health protection of children and youth","Children and the family".

In the context of improving the environmental situation in the region, upon an initiative of the Directorate three programs have been established and are currently operating: "The provision of drinking water to the population of the Saratov region in 2011-2015", "Environmental improvement of the Saratov region in 2009-2013", "Provision of the system for chemical and biological safety of the Saratov region in 2009-2013"; Decisions and Orders of the Government of Saratov region No. 258-P dated 18.06.2008 "On the contribution to the social and hygienic monitoring in the Saratov region", Order No. 6 dated 21.01.2005 "On the prevention of iodine deficiency." The activities for prevention of micronutrient deficiency in the diet of the population of the Saratov region are managed by the Federal Service for Consumer Rights Protection and Human Welfare (Rospotrebnadzor) in the Saratov region on a permanent basis and are supported by the Government of the Saratov region in cooperation with the relevant ministries, authorities and organizations.

The annual monitoring of nutritional status of the adult and child population and of production of nutritionally fortified foods is carried out. Today the levels of consumption of milk and dairy products, fruit, vegetables, potatoes and eggs remain low compared with physiological norms. Consumption of sugar and confectionery, bread, baked goods, pasta exceeds the physiological norm.

In order to prevent micronutrient deficiencies associated with unbalanced diet of the population, the following orders of the Government in the Saratov region were adopted and are acting on the initiative of the Directorate: "On the enrichment of products of mass consumption with micronutrients and supply of these products to the population of the Saratov region", "On additional measures for the supply of the region's population with mass consumption products enriched with micronutrients".

In accordance with the law of the Saratov region No. 138-ZSO "On Amendments to the Law of the Saratov region "On Education" starting from 01.01.2010 each child studying in elementary school gets a free glass of milk every day. At the Dairy Plant "Engelssky" JointStock Company (OAO) two production lines have been installed for production of "School milk", including milk enriched with vitamins.

In total there are 30 companies in the Saratov region producing fortified products (breadbaking complexes, bakeries, milk-processing plants, plants producing drinking water packaged 
in containers, confectionary plants). This is slightly more than $4 \%$ of the total number of enterprises in the food processing industry that is below the average level for the Russian Federation.

As the main reason of the low activity, the local manufacturers indicate the lack of the sustained consumer demand for fortified products. However, on the part of the enterprises, the advertising of such products is insufficient, and the form of its presentation is ineffective.

Given the significance of the problems associated with the promotion of a healthy diet, on the initiative of the Directorate of the Federal Service for Consumer Rights Protection and Human Welfare (Rospotrebnadzor) in the Saratov region, with the support of the Government of the Saratov region, in 2010 in Saratov a regional scientific and practical conference was held with participation of V.A. Tutelian, an academician, Professor, Doctor of Medical Sciences, director of the State Institution Scientific Research Institute of Nutrition of the Russian Academy of Sciences. According to the results of the conference a resolution was adopted, the project was drafted and the Concept of healthy nutrition in the population of the Saratov Region until 2020 was approved. The tasks of the Concept include the development of the local production of fortified foods. In order to raise the awareness of the population on the measures of prevention of micronutrient deficiency, development of the culture of healthy nutrition and healthy lifestyle, mass media, educational programs and public speaking platforms for different audiences are used. Thus, in $85.0 \%$ of schools in the region the program "Speaking about Healthy Nutrition" is implemented for 1-6 school grades. Every year the talk about a balanced diet is held in schools during the first parent meeting. Classes on this subject are held during quarterly workshops for healthcare specialists. Specialists of the Directorate of the Federal Service for Consumer Rights Protection and Human Welfare (Rospotrebnadzor) in the Saratov region make presentations and reports on preventive nutrition at the meetings and workshops with dieticians, nutritionists, hospital nutrition units workers, heads of educational and industrial enterprises, etc.

The questions of food culture and prevention of micronutrient deficiencies in the diet are included in the program of basic standards of sanitation for decreed categories of workers; the training is conducted on the basis of the Federal State-Funded Healthcare Institution "Centre for hygiene and epidemiology in the Saratov region".

In August of 2013 the issue of the provision of the region's population with fortified foods was addressed at a meeting with the Deputy Chairman of the Government of the Saratov region. The meeting resulted in a decision accompanied by the list of instructions to ministries and heads of food and processing industry, aimed at organization of support of manufacturers of fortified products and strengthening of awareness-building efforts. 


\section{References}

1. Veden'kina L.K. Mikronutrientnyj status i zdorov'enaselenija Rjazanskojoblasti: problemy biomonitoringa [Micronutrient status and health in the Ryazan Region citizens: monitoring issues]. Zdorovoe pitanie: vospitanie, obrazovanie, reklama: materialy VIojVserossijskoj konferencii, Moscow, 2001, pp. 36-37.

2. Tutel'jan V.A., Spirichev V.B., Suhanov B.P., Kudasheva V.A. Mikronutrienty v pitanii zdorovogo i bol'nogo cheloveka [Micronutrients in the diet of healthy and sick individuals]. Moscow: Kolos, 2002. 424 p.

3. Mazo V.K., Kodencova V.M., Vrzhesinskaja O.A., Peneva V.V. Mikronutrienty i antioksidanty $\mathrm{v}$ sostave obogashhennyh i funkcional'nyh pishhevyh produktov [Micronutrients and antioxidants contained in enriched and functional food products]. Vestnikvosstanovitel'nojmediciny, 2013, no. 2, pp. 55-58.

4. Onishhenko G.G., Tutel'jan V.A. Sovety specialistov po pravil'nomu i zdorovomu pitaniju [Professional advice on nutritional and healthy eating]. Tovarovedprodovol'stvennyhtovarov, 2009, no. 3, pp. 55-56.

5. Rabotaev E.F., Hohlova E.A. Aktual'nye problemy mikronutrientnoj nedostatochnosti v Chuvashskoj Respublike [Acute issues of micronutrient deficiency in the Chuvash Republic]. Gigiena i sanitarija, 2009, no. 1, pp. 36-38.

6. Gromova O.A., Torshin I.Ju., Tetruashvili N.K., Lisicyna E.Ju. Sistematicheskij analiz vzaimosvjazi deficitavitaminov i vrozhdennyh porokov razvitija [Systems analysis of the relationship between vitamin deficiency and congenital malformations]. Consilium Medicum (Vrachebnyj konsilium), 2012. vol. 14, no. 6, pp. 34-40.

7. Hotimchenko S.A., AlekseevaI.A., BaturinA.K. Rasprostranennost' i profilaktika deficitazheleza $\mathrm{u}$ detej i beremennyh zhenshhin: vlijanie pishhevogo faktora [The prevalence and prevention of iron deficiency in children and pregnant women: the influence of the food factor]. Rossijskijpediatricheskijzhurnal, 1999, no. 1,pp. 21-29. $119-129$.

8. Aggett P.J. Trace elements of the micropremie. Clin Perinatal, 2000, vol. 27, no. 1, p.

9. Hodis H. et al. Antioxidant vitamin intake reduces progression of carotid artery intiina media thickness. Circulation, 1996, vol. 94, suppl. 1, p. 1508.

10. Grischka E.M. Nutrition during pregnancy - current aspects. MMW. Fortschr. Med, 2004, vol. 146, pp. 29-30.

11. Kashyap S. et al. Growth, nutrient retention and metabolic response in low birthweght infant fed varying, intakes of protein and energy. J. Pediatr, 1988, vol. 113, p. 713. 